\title{
DIGITAL-IMAGE ANALYSIS TO PREDICT WEIGHT AND YIELDS OF BONELESS SUBPRIMAL BEEF CUTS
}

\author{
Gustavo Adolfo Teira ${ }^{1 *}$; Eduardo Tinois²; Roberto de Alencar Lotufo ${ }^{3}$; Pedro Eduardo de Felício ${ }^{4}$ \\ ${ }^{I}$ Depto. de Industria de Alimentos, Universidad Nacional de Entre Ríos, 3200 - Concordia, ER, Argentina. \\ ${ }^{2}$ UNICAMP/CEB, C.P. 6040 - 13084-971 - Campinas, SP - Brasil. \\ ${ }^{3}$ UNICAMP/FEEC - Depto.de Engenharia de Computação e Automação Industrial , C.P. 6101 - 13083-970 - \\ Campinas, SP - Brasil. \\ ${ }^{4}$ UNICAMP/FEA - Depto. de Tecnologia de Alimentos, C.P. 6121 - 13081-970 - Campinas, SP - Brasil. \\ *Corresponding author <teirag@fcal.uner.edu.ar>
}

\begin{abstract}
For several decades, beef carcass evaluation for grading or research purposes has relied upon subjective visual scores, and manually taken measurements, but in recent times there has been a growing interest in new technologies capable of improving accuracy of estimates. Equations to predict weight and yield of beef pistol subprimal cuts were developed in this work using digital image analysis (VIA) of the $12^{\text {th }}$ rib steak. Equations to predict total pistol subprimal cuts weight (CUTS) had coefficients of determination (CD) of 0.84 , or 0.87 to 0.88 , when the independent variables were the VIA parameters and the half carcass weight (HC) or the total pistol weight (TP), respectively. The predicted values for the total seven subprimal cuts, as a percentage of half carcass weight (CUTS\%), presented CD values ranging from 0.37 to 0.47 , or 0.21 to 0.31 , using $\mathrm{HC}$ or TP as a principal independent variable. Likewise, the equation for weight of the individual subprimal cuts had CD values ranging from 0.40 to 0.72 , or 0.43 to 0.74 using $\mathrm{HC}$ or TP, respectively. In this research, the developed VIA procedure has demonstrated good repeatability and accuracy to estimate the total pistol subprimal weights, and some individual subprimal weights.

Key words: beef industry, beef carcass, image analysis, rib eye area, fat thickness
\end{abstract}

\section{ANÁLISE DE IMAGEM DIGITAL PARA A PREVISÃO DE PESOS E RENDIMENTOS DE CORTES DE CARNE BOVINA}

\begin{abstract}
RESUMO: Por várias décadas, a avaliação de carcaça bovina em sistemas de tipificação ou em pesquisas tem dependido de escores subjetivos e medidas obtidas manualmente, mas ultimamente tem havido um crescente interesse por novas tecnologias capazes de aumentar a acurácia das estimativas. Este trabalho teve como objetivo desenvolver equações para a previsão de pesos e rendimentos de cortes bovinos, através da análise de imagem digital (VIA) de uma seção do contrafilé da $12^{\text {a }}$ costela. As equações de previsão do peso dos cortes do traseiro especial (CUTS) apresentaram coeficientes de determinação (CD) de 0,84 e de $0,87-0,88$, quando as variáveis independentes usadas eram os parâmetros VIA e o peso da meia carcaça (HC) ou o peso total do traseiro especial (TP), respectivamente. As equações de previsão do rendimento dos cortes do traseiro especial (CUTS\%) representaram de 37,1 a 46,8\% e de 21,3 a 30,6\% da variação total, quando a principal variável independente utilizada na equação era $\mathrm{HC}$ ou TP, respectivamente. Nas equações de previsão dos pesos individuais dos cortes do traseiro especial o $C D$ variou de $0,40-0,72$ e de $0,43-0,74$, usando as variáveis $\mathrm{HC}$ ou $\mathrm{TP}$, respectivamente. $\mathrm{O}$ sistema de análise de imagem digital utilizado apresentou boa repetibilidade, podendo ser considerado um procedimento confiável para a estimativa do peso em cortes do traseiro especial e de alguns dos seus cortes individuais.

Palavras-chave: indústria da carne, carcaça bovina, análise de imagem, área de olho de lombo, espessura de gordura
\end{abstract}

\section{INTRODUCTION}

The value of beef cuts should reflect both consumer demand and reliability, and marketing standards which emphasize quality, uniformity and consistency of the meat. Therefore, an evaluation procedure for predicting weights and yields of carcasses and beef retail cuts becomes of great importance for the beef industry (Cross \& Belk, 1994).

Several studies have described different methods that have great potential for industrial applications: ultrasound, video-image analysis, nuclear magnetic resonance, optical probes and bioelectrical impedance. These technologies have been used successfully in laboratories. 
However their utilization in the beef industry is restricted. Only fast, consistent, accurate, non-destructive and reasonable priced methods are of interest to the industry (Swatland, 1995).

Digital image analysis has been identified as the most efficient procedure to evaluate yield of beef carcasses (Cross et al., 1983). It has also been utilized for other purposes: determination of color and fat thickness (Monin, 1998), marbling scores in beef (Albrecht et al., 1996) and pork (Scholz et al., 1996) and water retention capacity in beef (Irie et al., 1996). Li et al. (1999) reported that tenderness of beef could be predicted on the basis of color, marbling and texture measures obtained by image analysis.

The use of this technique has been reported to develop an objective system for carcass classification which has been used as a standard of payment to European Union beef producers based mainly on the determination of conformation and finish traits (Borggaard et al., 1996). Other studies have reported the use of video image analysis of steaks removed from the $12^{\text {th }}$ rib for prediction of weight and yield of subprimal cuts (Cross et al., 1983; Wassenberg et al., 1986; Shackelford et al., 1998).

No information on the use of such systems for the determination of traits of carcasses and cuts produced from Zebu steers, predominantly slaughtered in Brazil, is available. In addition, it is necessary to follow current trends concerning international beef commercialization. The objectives of this work were to predict weight and yield of whole and individual pistol cuts by regression equations using variables obtained through image analysis of the $12^{\text {th }}$ rib steak, and to test the accuracy and repeatability of the procedure.

\section{MATERIAL AND METHODS}

Selection of carcasses - Carcasses produced from 51 Nelore crossbred steers, slaughtered at Bertin beef processing plant (Lins, SP-Brazil) were selected according to various carcass weight, maturity and fatness to obtain a trait variability as large as possible.

Cuts utilized - Carcasses were chilled for 24 hours (1 $-2^{\circ} \mathrm{C}$ ) and broken between the $5^{\text {th }}$ and the $6^{\text {th }}$ rib into hindquarter (HQ) and forequarter (FQ). The former was separated from flank and plate (FP) using a saw and knife, $50 \mathrm{~mm}$ to the side of the Longissimus muscle to obtain the pistol (TP). This was further boned to obtain the following cuts: top round, bottom round, eye round, knuckle, rump, cube roll \& strip loin, and tenderloin side strap off. Connective tissue, subcutaneous fat and trimmings were separated following the standard procedure for cuts exported to Germany by the beef plant.
Sample preparation - A $2.5 \mathrm{~cm}$ steak sample was removed from the $12^{\text {th }}$ rib before boning each cube roll $\&$ strip loin, and the rib eye area of the steak was delineated for later measurement with a compensating polar planimeter. The sample weight was not considered in the total weight of the cut.

Image analysis - Images were captured using a Sony ${ }^{\circledR}$ digital camera, MVC-FD71. Bone-in steak samples were placed flat on a non-glare black surface and illuminated with two tungsten, $150 \mathrm{~W}$ halogen bulbs. A reference white square paper was positioned on the black surface, next to the object such that the same distance and focus were kept when images were captured.

Digital images, saved in a 3.5" floppy disk, were processed using Matlab Mathematical Morphology Toolbox (Barrera et al., 1998). With these tools, a program for segmentation of the original digital image and extraction of selected parameters was developed. Figure 1a: input image (a known square is included in the image to calibrate the pixel dimensions).

To compute the total rib steak area (Figure 1b, TRSA, $\mathrm{cm}^{2}$ ) the total rib was extracted from the background using a standard thresholding technique. The image illustrates only the contour of the rib and the square. The rib eye area (Figure 1c, REA, $\mathrm{cm}^{2}$ ) was detected by an automatic procedure based on the so-called watershed transform (Beucher \& Meyer, 1993; Lotufo \& Falcao, 2000). First the input image was pre-processed by an edge enhancement procedure. Then the best closed contour was found based on a prior knowledge of the approximate position of the rib eye. The watershed transform was responsible to find the best closed contour on the edge enhanced image. The rib eye area percentage (REA\%) resulted from REA/TRSA x 100 .

Fat thickness (FT, mm) is shown in Figure 1d. The black line indicates where the thickness was measured. This line was automatically drawn perpendicular to the rib eye contour. It was traced from a point located on a straight line segment determined by the ends of the rib eye at $1 / 4$ of its length from the left.

A rectangle was automatically generated from the points of the rib eye ends (Figure 1e). It shows the location and subsequent extraction of fat area, determined by subcutaneous fat in the lower part of rib eye area (Figure $1 \mathrm{f}, \mathrm{FA}, \mathrm{cm}^{2}$ ). This parameter was measured from an image generated using a thresholding technique to detect the fat area. Dark pixels were not considered and white pixels (fat) were counted. The fat area percentage (FA\%) resulted from FA/TRSA x 100 .

Statistical analysis - VIA parameters and measured side carcass traits were statistically analyzed to select the best linear regression equations for weight and yield prediction. These equations were assessed using the coefficient of determination (CD), statistical Cp (Mallows, 1973) and 
mean square error (MSE) with Stepwise/Maxr procedure, SAS Institute (1985). A second image was captured to test repeatability of the VIA procedure following the Bland \& Altman (1986) methodology.

\section{RESULTS AND DISCUSSION}

Table 1 shows mean values, standard deviation, maximum and minimum values obtained for the 51 half carcasses used in the present study. The great variability shown by the dependent and independent variables were expected on account of the applied selected methodology.

The pistol subprimal cut weights (CUTS), their weight as a percentage of the half carcass weight (CUTS\%) and the weight of individual pistol subprimal cuts did not presented correlations $(P>0.01)$ with the VIA parameters. These parameters however in some cases were correlated $(P<0.01)$ : TRSA and REA $(\mathrm{r}=0.62)$, REA and REA $\%$ $(\mathrm{r}=0.82)$, FT and FA $(\mathrm{r}=0.59)$, FT and FA $\%(\mathrm{r}=0.59)$ and FA and FA\% $(r=0.98)$. Rib eye area, measured by both VIA (REA) and manually with a planimeter (AOLPLAN) presented a significant correlation $(P<0.01)$ of 0.70 . The graphic representation of the observed values of CUTS and CUTS\% variables against independent variables used did not show non-linear relationships.

Weight prediction of the seven subprimal cuts - To obtain the prediction equation of the CUTS variable, the two best individual indicators, $\mathrm{HC}$ or TP and all VIA param-
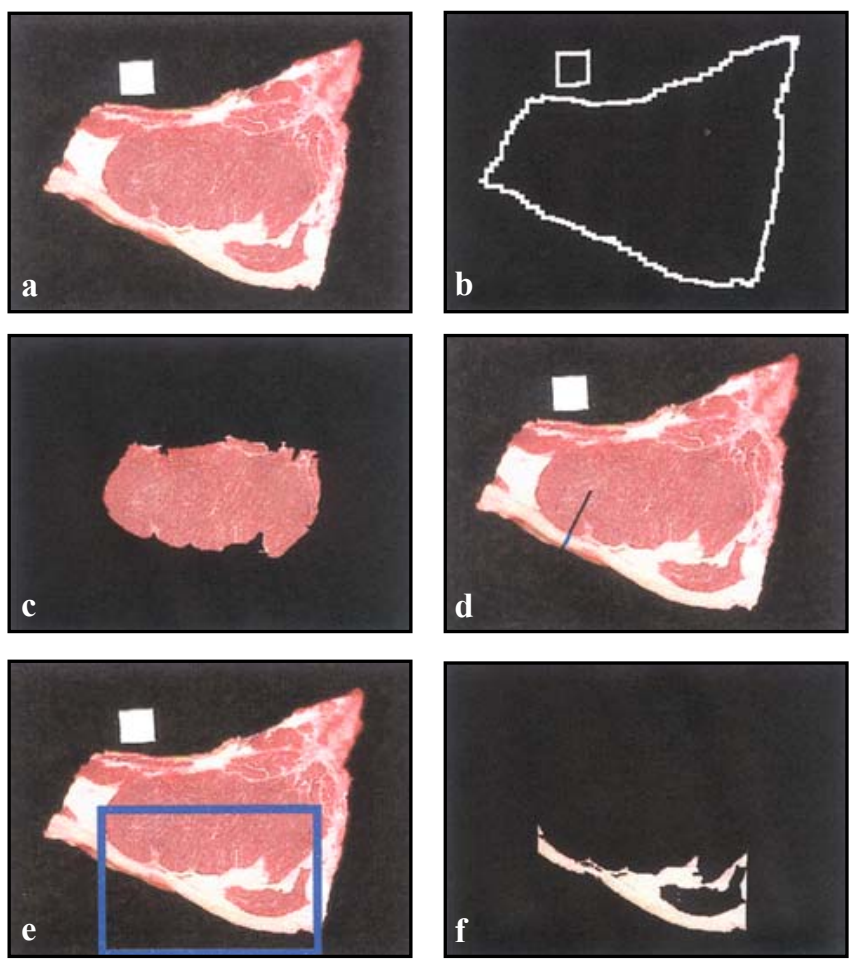

Figure 1 - Segmentation of selected parameters. a) original digital image of a rib steak. b) total rib steak area. c) rib eye area. d) fat thickness. e) fat area location. f) fat area. eters were used (Tables 2 and 3). When the $\mathrm{HC}$ variable was used, the best equations accounted for 83.5 to $84.0 \%$ of the observed variation of the subprimal cut weights. When HC was replaced by TP, the coefficient of determination of the best equations varied from 0.87 to 0.88 .

In order to select the most adequate models of regression equations, belonging to the same subset of variables, a Cp graph (Mallow statistics) was plotted against $p$ (number of parameters included in the equation). If there was no bias, $\mathrm{Cp}$ should be equal to $\mathrm{p}$. In practice, models of Cps near to, but preferably less than $\mathrm{p}$, should be chosen (Pike, 1986).

Table 1 - Descriptive statistics of dependent and independent variables $(\mathrm{N}=51)$.

\begin{tabular}{|c|c|c|c|c|}
\hline Variable $^{1}$ & Mean & S.D. & Minimum & Maximum \\
\hline \multicolumn{5}{|c|}{ Dependent Variables } \\
\hline CUTS (kg) & 29.4 & 2.18 & 25.1 & 34.2 \\
\hline CUTS\% & 21.4 & 0.86 & 19.7 & 23.5 \\
\hline TOPR (kg) & 5.6 & 0.42 & 4.5 & 6.4 \\
\hline BOTTR (kg) & 3.2 & 0.30 & 2.5 & 3.8 \\
\hline EYER (kg) & 2.4 & 0.28 & 1.9 & 3.4 \\
\hline KNUC (kg) & 5.0 & 0.43 & 4.0 & 5.8 \\
\hline RUMP (kg) & 5.4 & 0.59 & 4.4 & 6.4 \\
\hline STRIPL (kg) & 6.0 & 0.59 & 5.1 & 7.6 \\
\hline TENDL (kg) & 1.8 & 0.21 & 1.4 & 2.3 \\
\hline \multicolumn{5}{|c|}{ Independent variables } \\
\hline $\mathrm{HC}(\mathrm{kg})$ & 137.3 & 12.70 & 119.4 & 165.6 \\
\hline TP (kg) & 65.2 & 5.58 & 55.2 & 76.8 \\
\hline FQ (kg) & 52.4 & 5.06 & 45.6 & 71.2 \\
\hline FP (kg) & 19.5 & 2.98 & 14.0 & 25.8 \\
\hline MATUR & 5.8 & 1.90 & 2.0 & 8.0 \\
\hline AOLPLAN $\left(\mathrm{cm}^{2}\right)$ & 67.3 & 7.70 & 48.4 & 84.9 \\
\hline TRSA $\left(\mathrm{cm}^{2}\right)$ & 156.2 & 11.70 & 127.0 & 195.1 \\
\hline REA $\left(\mathrm{cm}^{2}\right)$ & 71.0 & 9.50 & 52.0 & 97.3 \\
\hline REA\% & 45.4 & 4.80 & 33.9 & 56.1 \\
\hline FT (mm) & 5.6 & 3.00 & 1.0 & 17.0 \\
\hline $\mathrm{FA}\left(\mathrm{cm}^{2}\right)$ & 12.4 & 4.60 & 4.0 & 24.6 \\
\hline FA $\%$ & 7.9 & 2.90 & 2.4 & 16.2 \\
\hline
\end{tabular}

${ }^{1}$ CUTS: seven pistol sub-primal cuts weight (kg). CUTS\%: seven pistol sub-primal cuts percentage. TOPR: top round weight $(\mathrm{kg})$. BOTTR: bottom round weight $(\mathrm{kg})$. EYER: eye round weight $(\mathrm{kg})$. KNUC: knuckle weight (kg). RUMP: rump weight $(\mathrm{kg})$. STRIPL: cube roll \& strip loin weight $(\mathrm{kg})$. TENDL: tenderloin side strap off weight $(\mathrm{kg})$. HC: half carcass weight $(\mathrm{kg})$. TP: total pistol weight $(\mathrm{kg})$. FQ: forequarter weight $(\mathrm{kg})$. FP: flank and plate weight $(\mathrm{kg})$. MATUR: maturity of carcass (number of permanent incisor teeth). AOLPLAN: rib eye area, measured with a planimeter $\left(\mathrm{cm}^{2}\right)$. TRSA: total steak area, measured by video image analysis (VIA, $\left.\mathrm{cm}^{2}\right)$. REA: rib eye area measured by VIA $\left(\mathrm{cm}^{2}\right)$. REA\%: rib eye area percentage, resulting of REA/TRSA x 100, measured by VIA. FT: fat thickness, measured by VIA (mm). FA: fat area, measured by VIA $\left(\mathrm{cm}^{2}\right)$. FA\%: fat area percentage, resulting of FA/TRSA x 100, measured by VIA. 
This kind of graphical representations, subsets corresponding to equations 1 to 6 (Table 2) and 7 to 12 (Table 3), indicates that the inclusion of VIA parameters results in obtaining the most appropriate models.

\section{Comparison of predictions in relation to carcass weight}

- The simultaneous graphic representation of both observed and predicted values of the CUTS variable, using the different regression equations, versus chilled carcass weight (kg) ranges (A:230-250; B:250-270; C:270-290; D:290310 ; E:310-330) conveniently selected, indicated the results of the different models under such conditions.

These equations including the $\mathrm{HC}$ variable tended to overestimate values for heavier carcasses (E range) and equations including the TP variable tended to underestimate values for lighter carcasses (A range). Equation $n^{\circ} 8$ (Table 3 ) was considered the most adequate for any weight range carcass. These observations were validated through the Tukey test of residue mean comparison (observed values minus predicted values) for each equation and weight range.
Prediction of total yield of seven pistol subprimal cuts - Prediction of yield accounted for 37.1 to $46.0 \%$ or 21.3 to $30.6 \%$ of the variation when the major independent variable was $\mathrm{HC}$ or TP, respectively (Tables 4 and 5).

Prediction of weight of individual pistol cuts - It is important to predict the weight of individual cuts in order to determine the true value of each carcass. That is why VIA parameters were used to develop different prediction equations. The results obtained (Table 6 and 7) presented coefficients of determination that varied from 0.40 to 0.72 or from 0.43 to 0.74 when the major independent variable was $\mathrm{HC}$ or TP, respectively. These prediction equations were considered satisfactory for some cuts (knuckle, rump) but they presented lower CDs than those reported by Shackelford et al. (1998). German export standards used at the Bertin beef plant may account for these lower values since the removal of all visible fat is required, connective tissue and the trimming of the cuts which may vary from one employee to another.

Table 2 - Prediction equations to estimate total pistol cut weights $(\mathrm{kg})$ using half carcass weights $(\mathrm{HC} ; \mathrm{N}=51)^{1}$.

\begin{tabular}{lccccccccccc}
\hline Eq.N & CD $^{2}$ & MSE & Cp & Interc. & HC & TRSA & REA & REA\% & FT & FA & FA\% \\
\hline 1 & 0.816 & 0.90 & 2.62 & 8.078 & 0.155 & & & & \\
2 & 0.835 & 0.82 & -0.61 & 8.974 & 0.155 & & & & & \\
3 & 0.836 & 0.83 & 1.11 & 8.974 & 0.155 & & & & & \\
4 & 0.837 & 0.85 & 2.96 & 9.765 & 0.153 & & & -0.029 & -0.105 \\
5 & 0.840 & 0.85 & 4.01 & 28.950 & 0.152 & -0.121 & 0.284 & -0.455 & 0.029 & -0.076 \\
6 & 0.840 & 0.87 & 6.00 & 28.220 & 0.152 & -0.117 & 0.274 & -0.439 & 0.005 & -0.077 \\
\hline
\end{tabular}

${ }^{1}$ Abbreviations are defined in the footnote of Table 1.

${ }^{2} \mathrm{CD}$ : coefficient of determination; MSE: mean square error; Cp: Mallow statistics; Interc: intersection.

Table 3 - Prediction equations to estimate total pistol cut weights $(\mathrm{kg})$ using total pistol weights (TP; $\mathrm{N}=51)^{1}$.

\begin{tabular}{|c|c|c|c|c|c|c|c|c|c|c|}
\hline Eq. $N^{o}$ & $\mathrm{CD}^{2}$ & MSE & $\mathrm{Cp}$ & Interc. & $\mathrm{TP}$ & TRSA & REA\% & FT & FA & FA\% \\
\hline 7 & 0.855 & 0.70 & 4.29 & 5.821 & 0.362 & & & & & \\
\hline 8 & 0.872 & 0.63 & 0.32 & 6.692 & 0.360 & & & & & -0.098 \\
\hline 9 & 0.877 & 0.62 & 0.59 & 4.088 & 0.372 & & 0.037 & & -0.049 & \\
\hline 10 & 0.879 & 0.63 & 2.07 & 4.107 & 0.371 & & 0.037 & 0.034 & -0.062 & \\
\hline 11 & 0.879 & 0.64 & 4.01 & 4.843 & 0.371 & -0.004 & 0.036 & 0.035 & -0.100 & \\
\hline 12 & 0.879 & 0.66 & 6.00 & 5.392 & 0.371 & -0.008 & 0.035 & 0.036 & 0.042 & -0.167 \\
\hline
\end{tabular}

${ }^{1}$ Abbreviations are defined in the footnote of Table 1.

${ }^{2} \mathrm{CD}$ : coefficient of determination; MSE: mean square error; Cp: Mallows'statistic; Interc: intersection.

Table 4 - Prediction equations estimate total pistol cut percentages, using half carcass weights (HC; $N=51)^{1}$.

\begin{tabular}{|c|c|c|c|c|c|c|c|c|c|c|c|c|}
\hline Eq. $N^{o}$ & $\mathrm{CD}^{2}$ & MSE & $\mathrm{Cp}$ & Interc. & $\mathrm{HC}$ & MATUR & TRSA & REA & REA\% & FT & FA & FA\% \\
\hline 13 & 0.371 & 0.47 & 2.67 & 27.11 & -0.041 & & & & & & & \\
\hline 14 & 0.446 & 0.43 & -1.32 & 27.81 & -0.042 & & & & & & & -0.082 \\
\hline 15 & 0.451 & 0.43 & 0.35 & 27.81 & -0.042 & & & & & 0.023 & & -0.096 \\
\hline 16 & 0.452 & 0.44 & 2.28 & 27.79 & -0.041 & -0.015 & & & & 0.021 & & -0.096 \\
\hline 17 & 0.453 & 0.45 & 4.14 & 26.63 & -0.040 & -0.021 & 0.007 & & & 0.018 & & -0.060 \\
\hline 18 & 0.468 & 0.45 & 5.00 & 43.58 & -0.042 & -0.017 & -0.097 & 0.227 & -0.360 & & -0.058 & \\
\hline
\end{tabular}

${ }^{1}$ Abbreviations are defined in the footnote in Table 1.

${ }^{2} \mathrm{CD}$ : coefficient of determination; MSE: mean square error; $\mathrm{Cp}$ : Mallows'statistic; Interc:intersection. 
Table 5 - Prediction equations to estimate total pistol cut percentages, using total pistol weights (TP; N=51) ${ }^{1}$.

\begin{tabular}{lcccccccccc}
\hline Eq.N & CD $^{2}$ & MSE & Cp & Interc. & TP & MATUR & TRSA & FT & FA & FA\% \\
\hline 19 & 0.213 & 0.59 & 1.63 & 26.09 & -0.071 & & & & & -0.083 \\
20 & 0.290 & 0.55 & -1.13 & 26.82 & -0.072 & & & & & -0.085 \\
21 & 0.297 & 0.55 & 0.41 & 26.71 & -0.067 & -0.042 & & & \\
22 & 0.304 & 0.56 & 1.97 & 25.11 & -0.066 & -0.052 & 0.010 & & -0.053 & \\
23 & 0.305 & 0.57 & 3.91 & 25.13 & -0.066 & -0.049 & 0.010 & 0.011 & -0.058 & \\
24 & 0.306 & 0.58 & 5.87 & 24.14 & -0.066 & -0.052 & 0.017 & 0.009 & -0.136 & 0.124 \\
\hline
\end{tabular}

${ }^{1}$ Abbreviations are defined in the footnote of Table 1.

${ }^{2} \mathrm{CD}$ : coefficient of determination; MSE: mean square error; $\mathrm{Cp}$ : Mallows'statistic; Interc: intersection.

Table 6 - Prediction equations to estimate individual pistol cut weights $(\mathrm{kg})$ using $\mathrm{HC}(\mathrm{N}=51)^{1}$.

\begin{tabular}{lccrrrrrrrrr}
\hline CUT & CD $^{2}$ & MSE & \multicolumn{1}{c}{ Cp } & Interc. & HC & TRSA & REA & REA\% & \multicolumn{1}{c}{ FT } & FA & FA\% \\
\hline TOPR & 0.452 & 0.11 & 7.11 & 8.342 & 0.019 & -0.033 & & & 0.020 & 0.355 & -0.600 \\
BOTTR & 0.426 & 0.06 & 4.28 & -1.636 & 0.015 & 0.020 & -0.040 & 0.058 & -0.012 & & \\
EYER & 0.396 & 0.05 & 4.11 & 0.157 & 0.014 & & 0.021 & -0.024 & & -0.108 & 0.163 \\
KNUC & 0.626 & 0.08 & 4.01 & 3.185 & 0.025 & -0.004 & -0.010 & & & 0.103 & -0.184 \\
RUMP & 0.721 & 0.11 & 4.53 & 11.212 & 0.035 & -0.061 & 0.141 & -0.240 & -0.016 & \\
STRIPL & 0.522 & 0.18 & 5.20 & 3.790 & 0.033 & 0.029 & & 0.018 & -0.281 & 0.431 \\
TENDL & 0.536 & 0.02 & 4.31 & -1.583 & 0.012 & 0.012 & -0.028 & 0.041 & & -0.001 & \\
\hline
\end{tabular}

${ }^{1}$ Abbreviations are defined in the footnote of Table 1.

${ }^{2} \mathrm{CD}$ : coefficient of determination; MSE: mean square error; Cp: Mallows'statistic; Interc: intersection.

Table 7 - Prediction equations to estimate individual pistol cut weights $(\mathrm{kg})$ using TP $(\mathrm{N}=51)^{1}$.

\begin{tabular}{lccccccccccr}
\hline CUT & CD $^{2}$ & MSE & Cp & Interc. & TP & TRSA & REA & REA\% & \multicolumn{1}{c}{ FT } & \multicolumn{1}{c}{ FA } & FA\% \\
\hline TOPR & 0.493 & 0.10 & 6.43 & 8.521 & 0.047 & -0.037 & & & 0.022 & 0.390 & -0.654 \\
BOTTR & 0.518 & 0.05 & 4.14 & -4.984 & 0.040 & 0.036 & -0.077 & 0.121 & -0.007 & & \\
EYER & 0.428 & 0.05 & 4.10 & -0.422 & 0.034 & & 0.008 & & 0.006 & -0.051 & 0.073 \\
KNUC & 0.737 & 0.05 & 4.21 & 1.186 & 0.065 & & -0.029 & 0.039 & & 0.142 & -0.238 \\
RUMP & 0.721 & 0.11 & 4.17 & 7.265 & 0.084 & -0.043 & 0.096 & -0.159 & & -0.018 \\
STRIPL & 0.472 & 0.20 & 5.89 & 0.095 & 0.074 & & 0.016 & & 0.025 & -0.058 & 0.069 \\
TENDL & 0.524 & 0.02 & 4.20 & -3.280 & 0.028 & 0.020 & -0.047 & 0.075 & 0.002 & & \\
\hline
\end{tabular}

${ }^{1}$ Abbreviations are defined in the footnote of Table 1.

${ }^{2} \mathrm{CD}$ : coefficient of determination; MSE: mean square error; Cp: Mallows'statistic; Interc: intersection.

Repeatability of the digital image analysis procedure

- Twenty five digital image sample duplicates were utilized to test repeatability of the procedure. VIA parameters determined from duplicates were used in regression equation $n^{\circ} 6$ to predict the CUTS variable. The new estimated values were compared to those predicted by the same equation using VIA parameters which were obtained with the 25 original images. The repeatability of the system remained within the established limits $( \pm 1.96$ S.D).

\section{CONCLUSIONS}

Weight prediction equations with a high degree of accuracy for pistol cuts were obtained using the digital image analysis procedure, equations $n^{\circ} 6$ and $n^{\circ} 12$ being especially recommended. When grouped according to chilled carcass weight range, prediction presented a tendency to over or underestimate extreme values (ranges $\mathrm{A}$ and E). However equation $\mathrm{n}^{\circ} 8$ made acceptable predictions for all considered weight ranges. Yield predictions of pistol subprimal cuts had a relatively low degree of accuracy. Prediction of individual pistol subprimal cut weights (kg) was good in some cases (knuckle, rump) but all values were below the expected. Current trends towards standardization of beef cuts especially for export require further work to be carried out along these lines to develop a "prototype" with features suitable for its implementation in industrial continuous lines.

\section{ACKNOWLEDGEMENTS}

To CAPES/SPU-Argentina for the scholarship, of the first author. Fundación Antorchas, Argentina, for par- 
tially funding this project. $\mathrm{Eng}^{\mathrm{o}}$ Pedro Bertin Beloto, R\&D manager of Bertin Beef Processing Plant, Lins, S.P.; Prof. Dr. Armando Infante, UNICAMP/IMECC, and Department of English from the School of Food Science at the University of Entre Ríos, Concordia, ER, Argentina.

\section{REFERENCES}

ALBRECHT, E.; WEGNER, J.; ENDER, K. A new technique for objective evaluation of marbling in beef. Fleischwirtschaft, v.4, p.11-16, 1996.

BARRERA, J.; BANON, G.J.; LOTUFO, R.A.; HIRATA JR., R. MMach: a mathematical morphology toolbox for the KHOROS system. Journal of Electronic Imaging, v.7, p.174-210, 1998.

BEUCHER, S; MEYER, F. The morphological approach to segmentation: the watershed transformation. In: DOUGHERTY, E.R. (Ed.) Mathematical morphology in image processing. New York: Marcel Dekker, 1993. cap.12, p.433-481.

BLAND, J.M.; ALTMAN, D.G. Statistical methods for assessing agreement between two methods of clinical measurement. The Lancet, v.1, p.307$310,1986$.

BORGGAARD, C.; MADSEN, N.T.; THODBERG, H.H. In line image analysis in the slaughter industry, illustrated by beef carcass classification. Meat Science, v.43, p.s151-s163, 1996.

CROSS, H.R.; BELK, K.E. Objective measurements of carcass and meat quality. Meat Science, v.36, p.191-202, 1994.

CROSS, H.R.; GILLILAND, D.A.; DURLAND, P.R.; SEIDEMAN, S. Beef carcass evaluation by use of a video image analysis system. Journal of Animal Science, v.7, p.908-917, 1983.

IRIE M.; IZUMO, A.; MOHRI, S. Rapid method for determining waterholding capacity in meat using video image analysis and simple formulae. Meat Science, v.42, p.95-102, 1996.
LI, J.; TAN, J.; MARTZ, F.A.; HEYMANN, H. Image texture features as indicators of beef tenderness. Meat Science, v.53, p.17-22, 1999.

LOTUFO, R.; FALCAO, A. The ordered queue and the optimality of the watershed approaches. In: GOUTSIAS, J.; VINCENT, L.; BLOOMBERG, D. (Ed.) Morphology and its application to image and signal processing. Dordrecht: Kluwer Academic, 2000. p.341-350. (Computational Imaging and Vision, 12)

MALLOWS, C.L. Some comments on Cp. Technometrics, v.15, p.661675, 1973.

MONIN, G. Recent methods for predicting quality of whole meat. Meat Science, v.49, p.s231-s243, 1998.

PIKE, D.J. A practical approach to regression. In: PIGGOT, J.R. (Ed.) Statistical procedures in food research. London: Elsevier Applied Science, 1986. cap.3, p.61-100.

SAS INSTITUTE. User's guide: Statistic. 5.ed. Cary: Statistical Analysis System Institute, 1985. 956p.

SCHOLZ, A.; PAULKE, T.; EGER, H. Determining the degree of marbling in the pig. Use of computer-supported video picture analysis. Fleischwirtschaft International, v.1, p.9-11, 1996.

SHACKELFORD, S.D.; WHEELER, T.L.; KOOHMARAIE, M. Coupling of image analysis and tenderness classification to simultaneously evaluate carcass cutability, longissimus area, subprimal cut weights, and tenderness of beef. Journal of Animal Science, v.76, p.2631-2640, 1998.

SWATLAND, H.J. Objective assessment of meat yield and quality. Trends in Food Science and Technology, v.6, p.117-120, 1995.

WASSENBERG, R.L.; ALLEN, D.M.; KEMP, K.E. Video image analysis prediction of total kilograms and percent primal lean and fat yield of beef carcasses. Journal of Animal Science, v.62, p.1609-1616, 1986.

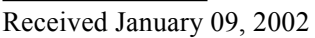

